\title{
4
}

\section{A Regulated Labour Trade across the Torres Strait: Papuan and New Guinean Domestic Workers in Australia, 1901-50}

\author{
Lucy Davies
}

In 1927, Beatrice Abel, a missionary at the Kwato Mission in the Territory of Papua, asked Alice Wedega, a young Papuan woman, to travel to Australia with the wife of a business manager from the nearby island of Samarai. The wife was an Australian expatriate and she wanted a Papuan 'girl' to accompany her to Australia to care for her children while she was on leave. Since Wedega had a desire to travel, and the only way for a Papuan woman to leave the country at the time was as a servant, she agreed to go. After one week of travel by ship with her employer and her employer's children, Wedega arrived in Sydney. Initially, Wedega revelled in the excitement of visiting a new city; however, following abuse from her employer, she wished to return to Papua. As Wedega later relayed in her autobiography, Listen, My Country, 'my employer didn't treat me as an ordinary girl at all, but as a kind of slave'. ${ }^{1}$ Wedega's meals consisted of the leftovers from her employer's meals, which she was given on the verandah or in her room. Wedega told Beatrice Abel's friend, who visited Wedega and took her to church in Sydney, that she was being abused and wished to return home. The friend wrote to Abel who wrote to Wedega's employer demanding that she allow Wedega to return home.

$1 \quad$ Wedega, Listen, My Country, 27. 
Wedega's employer refused to release her until she had fulfilled her three months of employment. When Wedega returned home to Papua at the end of the three months, she relayed her experience to her Papuan friends and warned them not to go to Australia to work. ${ }^{2}$

If experiences of labour mobility provide insight into the nature of Australian coloniality, a focus on Papuan and New Guinean domestic workers like Alice Wedega brings fresh understanding by highlighting the experience of women in twentieth-century Australia. ${ }^{3}$ The history of the regulated labour trade in Papuan and New Guinean domestic workers remains largely unrecorded. ${ }^{4}$ To date, Alice Wedega's autobiography is the only first-person account of a Papuan woman who worked as a domestic labourer in Australia. Donald Denoon has written about a Papuan woman, Tessie Lavau, who worked in Australia as a domestic in the 1950s, and has explored how her application to travel to Australia triggered a re-evaluation of Australia's governance of Papua New Guinea. ${ }^{5}$ These histories are important for drawing attention to Papuan and New Guinean domestic workers' experiences of labour in Australia and how their travels to Australia destabilised colonial rule. However, these were not isolated cases. Drawing out traces of evidence within Australian Government records from the beginning of the twentieth century to the 1950s, I show that Papuan and New Guinean women regularly travelled to Australia to work as servants, nursemaids and domestics. ${ }^{6}$

The collecting of information on Papuan and New Guinean domestic workers - which included surveillance of domestic workers' travels to and from Australia, visitations to domestic workers' places of employment and residence, interviews with domestic workers and their employers, and conversations with neighbours and police about domestic workersshows how, like Aboriginal domestic workers, their 'very presence in

\footnotetext{
2 Wedega, Listen, My Country, 27-29.

3 Throughout this chapter, Papua New Guineans, as they are known today, will be referred to separately as Papuans and New Guineans to accurately reflect the terms used at the time. The south and north of the east of the island of New Guinea were governed separately until after the World War II, when they were combined in an administrative union governed by Australia as the Territory of Papua and New Guinea. It was not until independence in 1975 that the 'and' between Papua and New Guinea was removed.

4 Davies, 'The Movement of Papuan Women'.

5 Denoon, A Trial Separation, 7-20; Denoon, 'Miss Tessie Lavau's Request', 136-42.

6 It is important to note here that Papuan and New Guinean men also regularly travelled to Australia to work as domestic labourers. While this chapter focuses on the experiences of Papuan and New Guinean women, for further reading on the complex role of Indigenous men in the private sphere, see Martínez et al., Colonialism and Male Domestic Service.
} 
the households of the colonizers was inherently destabilizing'. ${ }^{7}$ Scholars have demonstrated how government surveillance of Aboriginal women and girls of mixed descent was 'a method of controlling and regulating Indigenous and non-Indigenous relations'. Government surveillance of Papuan and New Guinean domestics, who were also often of mixed descent, served a similar function. ${ }^{8}$ As administrators of Papua and New Guinea, Australian officials were anxious that Papuans' and New Guineans' interactions with Australian citizens on the Australian mainland might have negative repercussions for indigenous and non-indigenous relations back in Papua and New Guinea; hence, Australian officials closely regulated Papuans' and New Guineans' travels to and from Australia.

The subtle ways in which Papuan and New Guinean domestic workers in Australia destabilised colonial relations in Papua and New Guinea have been largely overlooked in histories of labour to date, in part due to the ambiguous nature of their work. As Victoria Haskins and Ann Scrimgeour have convincingly argued, during the first half of the twentieth century, domestic work in Australia was widely regarded as not reallabour. ${ }^{9}$ Histories of Papuan and New Guinean labourers during the Pacific War-a period that has been identified as transformative in weakening Australia's control in Papua and New Guinea-have not considered how Papuan and New Guinean domestics working in Australia might have influenced labour relations in the two territories. ${ }^{10}$ Thus, a study of Papuan and New Guinean domestic workers in Australia provides an important avenue for telling the history of women's experiences of Australia's administration of Papua and New Guinea in the first half of the twentieth century, and for rethinking dominant understandings of the process (and timing) of decolonisation.

Anne Dickson-Waiko has recorded her own and other Papua New Guinean women's experiences of colonial rule, focusing especially on the role of women in the decolonisation of Papua New Guinea during the 1960s and 1970s. However, histories of Papua and New Guinea prior to the Pacific War have generally overlooked Papuan and New Guinean

\footnotetext{
$7 \quad$ Haskins, 'From the Centre to the City', 155.

8 Austin, 'Cecil Cook, Scientific Thought', 104-05; McGinn, 'Commonwealth Control', 28.

9 Haskins and Scrimgeour, "'Strike Strike, We Strike”, 89.

10 For a recent analysis of the Australian Government's anxieties about a breakdown in colonial order in Papua and New Guinea as a consequence of Papuans' and New Guineans' interactions during the Pacific War, see Banivanua Mar, Decolonisation and the Pacific, 127-28.
} 
women labourers. ${ }^{11}$ In her 2016 book, Decolonisation and the Pacific, Tracey Banivanua Mar demonstrated how decolonisation in the Pacific consisted of a range of 'subtle expressions ... that expanded beyond the territorial confines of colonial and national borders'. ${ }^{12}$ This chapter adopts Banivanua Mar's interpretation of decolonisation as a gradual process, propelled by indigenous people, that took place in a range of spaces and over a long period of time and applies it to the private sphere. It argues that what went on in the homes of Australians who employed Papuan and New Guinean domestics, such as sexual liaisons and everyday interactions between domestic workers and their employers, had ramifications for the wider colonial order in Papua and New Guinea. As Ann Laura Stoler has established, interactions between people within these 'intimate sites' were 'critical to the making of colonial categories' and in distinguishing 'between ruler and ruled'. ${ }^{13}$ By focusing on how Papuan and New Guinean domestics tested colonial categories when they travelled to Australia to work, this chapter expands our current knowledge of colonialism and decolonisation across borders by recognising Papuan and New Guinean women as important actors in these processes.

\section{'Part of the Family': Papuan and New Guinean Domestic Labourers in Australian Homes}

During the late nineteenth century, after employing around 60,000 people from islands in the south-western Pacific in the sugar industry from 1863, the colony of Queensland gradually extended its border north towards the island of New Guinea, annexing the south-eastern corner of that island in $1883 .{ }^{14}$ It became a British protectorate the following year. In 1885 , Britain and Germany divided the eastern side of the island of New Guinea with Germany in the north (German New Guinea) and Britain in the south (British New Guinea). ${ }^{15}$ While Britain and Germany negotiated where to draw boundaries across the island of New Guinea, on the Australian mainland momentum for the federation movement grew and the colony of Queensland became part of the Australian Commonwealth in 1901. The Immigration Restriction Act 1901 (Cwlth) and the Pacific

11 Dickson-Waiko, 'Women, Nation and Decolonisation', 177-93.

12 Banivanua Mar, Decolonisation and the Pacific, 4.

13 Stoler, Carnal Knowledge and Imperial Power, 8.

14 Banivanua Mar, Violence and Colonial Dialogue, 1.

15 van der Veur, Search for New Guinea's Boundaries, 25. 
Island Labourers Act 1901 (Cwlth) were passed through the newly formed Commonwealth Parliament, signalling the new nation's hostility towards non-white peoples, including Aboriginal Australians and people from the Pacific. The Pacific Island Labourers Act placed conditions on Pacific Islanders who lived and worked on the Australian mainland and stipulated that there would be a gradual reduction in the number of Islanders entering Australia up to 31 December 1904 when recruitment would end. ${ }^{16}$ With the exception of those born in Australia, crews of ships and those with certificates of exemption under the Immigration Restriction Act, all Islanders in Australia on 31 December 1906 were deported. ${ }^{17}$

While people from the islands in the south-western Pacific were being excluded from the newly formed Commonwealth of Australia, indigenous people from the island of New Guinea were able to travel as domestic labourers to the Australian mainland with certificates of exemption. The Papuan and New Guinean men and women who travelled to Australia as domestic workers at the beginning of the twentieth century made up some of the earliest labourers in a new colonial labour trade between the island of New Guinea and Australia. As Barry Higman has argued, non-white domestic workers were accepted during the 'White Australia' policy era on the basis that 'domestics were employed in the private, feminine sphere rather than the public, male workplace'; 'the labour of housework was not classified as real work or employment'; and 'because domestic servants worked in scattered, small workplaces (households)', which meant that 'they were thought less threatening and less likely to be organized'. ${ }^{18}$ These assumptions about domestic labourers and their work, which were prevalent in government reports and correspondence about Papuan and New Guinean domestics, placed workers in an ambiguous position. By not being regarded as real labourers, and as a consequence of the isolation of their workplace, domestics were vulnerable to exploitation and abuse. Conversely, domestic workers often had an intimate knowledge of their employers and were able to build up a rapport with them over many years, leaving them in a better position than other Papuan and New Guinean labourers to negotiate directly with their employers. It was this ambiguous position that made Papuan and New Guinean domestic workers' experiences of labour in Australia unique, and it is with this context in mind that the actions of Papuan and New Guinean domestics

16 Tavan, The Long Slow Death of White Australia, 8.

17 Mercer, White Australia Defied, 76.

18 Higman, 'Testing the Boundaries of White Australia', 16. 
are best understood. As Banivanua Mar pointed out in her analysis of the Pacific Island labour trade in Queensland, 'resistance or agency take their meaning only from the oppressive context against which they are being asserted' ${ }^{19}$ Examining how Papuan and New Guinean domestics, such as Paula Wessel (discussed below), expressed 'attenuated agency' during their time in Australia provides a deeper understanding of how colonialism affected their lives. ${ }^{20}$

One of the first domestic workers to arrive in the recently federated Commonwealth of Australia from the island of New Guinea was Kumuessa, an indigenous woman from Rogea Island in British New Guinea. Kumuessa's travel conditions were typical for many Papuan and New Guinean domestic workers seeking to enter Australia. In August 1903, Kumuessa travelled to Sydney as the 'female attendant' of Ellen Turner, wife of the resident magistrate at Samarai in British New Guinea, Charles Owen Turner, who was visiting Australia with her husband. ${ }^{21}$ As an indigenous person from British New Guinea, Kumuessa was issued a certificate of exemption to enter Australia; she was required to leave Australia at the end of her work contract, at which point her certificate would be cancelled. Kumuessa accompanied Ellen Turner back to Samarai in January 1904.22 During the British, German and then Australian administration of the east of the island of New Guinea, it was accepted practice for expatriate officials and their wives to travel to Australia for leave accompanied by a Papuan or New Guinean domestic servant.

Australias administration over the south-east of the island of New Guinea officially began in 1906 following the Papua Act 1905 (Cwlth), which transferred authority from Britain to Australia. ${ }^{23}$ In keeping with the style of the British administration, Australia governed Papua in a colonial fashion, with expatriate officials and a strict labour hierarchy that included few educational opportunities for Papuans. From 1905 to 1940, mission schools subsidised by Australia provided the only educational

19 Banivanua Mar, Violence and Colonial Dialogue, 12.

20 Russell employs the term 'attenuated agency' to examine Aboriginal Australians' choices and actions within constrained circumstances. See Russell, Roving Mariners, 6.

21 NAA: BP342/1, 9115/327/1903, Immigration Restriction Act 1901 Certificate, particulars of coloured persons leaving the Port of Cooktown, Queensland, for parts within the Commonwealth per 'Wyandra', 14 August 1903.

22 NAA: BP342/1, 9115/327/1903, Burns Philp \& Co. Ltd on Board S.S. Airlie at Cooktown, 20 January 1904.

23 Papua Act 1905, Federal Register of Legislation, accessed 31 May 2017, www.legislation.gov.au/ Details/C1905A00009. 
opportunity for Papuans. ${ }^{24}$ Australia's control over the east of the island of New Guinea expanded during World War I (WWI) into German New Guinea. The Australian Naval and Military Expeditionary Force governed the region in a notoriously harsh manner and maintained many of the German policies that controlled New Guinean labourers. When WWI ended, the treaty of peace, signed at Versailles in France on 28 June 1919, officially brought Germany's control of New Guinea to an end. A few months before the Treaty of Versaille was signed, on 16 April 1919, Paula Wessel was born on Garowe Island off the coast of New Britain, the largest island in the Bismarck Archipelago. ${ }^{25}$ Wessel's father was a German plantation manager at Lama, Witu, and her mother, Nothe, was New Guinean. The couple were not married but lived together for some months until Wessel's father disappeared. ${ }^{26}$ By their very existence, Papuan and New Guinean children whose fathers were European and whose mothers were indigenous posed a challenge to racial divisions and hierarchies, and thereby Australia's authority in Papua and New Guinea. As John Dademo Waiko has argued, 'the white men established, protected, and maintained a dominant political and economic position by claiming to be a superior race who regarded New Guineans as inferior'. ${ }^{27}$ Australians lived in fear that the majority Papuan and New Guinean population would revolt against them. To create and reinforce racial division and hierarchy, they imposed strict regulations on Papuans and New Guineans that dictated where they could walk, sit and stand, during what hours and for what purpose. In 1933, under native labour regulations, all Papuan employees except domestic servants had to live outside of Port Moresby. ${ }^{28}$ Like many of the regulations that governed Papuans' and New Guineans' movements, the master-servant relationship was haunted by Australians' insecurity about their precarious control over Papuans and New Guineans. ${ }^{29}$

\footnotetext{
24 Waiko, A Short History of Papua New Guinea, 51.

25 NAA: A367, C72805, John W. Burton, General Secretary, Methodist Overseas Missions, to John L. Froggatt, 2 July 1942; NAA: A435, 1945/4/4736, Alfred R. Gardner, General Secretary, Methodist Overseas Missions, to A. R. Peters, Acting Secretary, Department of Immigration, re 'Paula Wessel', 14 August 1945. Encl. signed J. L. Froggatt.

26 Some reports claim that he died, others that he returned to Germany. See NAA: A12508, 21/4641; NAA: A367, C72805, J. K. McCarthy, Inter-Allied Services Department, to J. L. Froggatt, Esquire, 6 July 1942. Report by Capt. J. K. McCarthy. N.G. 3015. I.S.D., 6 July 1942.

27 Waiko, A Short History of Papua New Guinea, 70-71.

28 Wolfers, Race Relations and Colonial Rule, 46-55.

29 Waiko, A Short History of Papua New Guinea, 71. See also Wolfers, Race Relations and Colonial Rule, 55 .
} 
In 1921, when Wessel was around two years old, Australia was granted a League of Nations mandate over the north-east region of New Guinea. From then until 1942, the former German colony was known as the Mandated Territory of New Guinea. ${ }^{30}$ Once Australia established civil administration there, some improvements were made to New Guineans' working conditions: recruitment was forbidden in specified areas; labourers had to be returned to their home at the end of their contract; and, in 1922, 'disciplinary punishments' were repealed from the Native Labour Ordinance 1920. ${ }^{31}$ However, labour continued to be prioritised over New Guineans' welfare and New Guineans continued to be relegated to working as menial labourers for colonial officials and expatriates. While the new mandate system brought some change to the old imperial system, the 'guardian-to-ward relationship' between the mandate powers and indigenous people continued. ${ }^{32}$ This relationship was replicated in the relationship between female Papuan and New Guinean domestic workers and their employers during Australia's administration. While under German administration, some female New Guinean domestic workers had worked as concubines for their single, male European employers; from 1917, unmarried New Guinean women and children could only be employed by married European women. ${ }^{33}$ The relationship between Papuan and New Guinean domestics and their Australian employers was regularly framed as being similar to that of parent and child, with many Australian officials referring to employers as the 'guardians' of domestic labourers. As was sometimes the case on pastoral stations in Australiawhere Aboriginal workers were often 'cast as children of motherly white women'-Papuan and New Guinean domestics were nebulously positioned somewhere between child, ward and servant within the homes of white Australians. ${ }^{34}$

In 1923, when Wessel was around three years old, a government official took her away from her mother and placed her at the Raluana School near Rabaul where she was brought up by the Methodist Mission. ${ }^{35}$

30 Waiko, A Short History of Papua New Guinea, 63.

31 Mair, Australia in New Guinea, 180-84.

32 Banivanua Mar, Decolonisation in the Pacific, 90.

33 Wolfers, Race Relations and Colonial Rule, 80-81.

34 Haskins and Scrimgeour, "Strike Strike, We Strike", 92.

35 NAA: A367, C72805, Daisy Coltheart, Girls Training Home, Cootamundra, to Mr. Froggatt, 6 July 1942; NAA: A367, C72805, J. K. McCarthy, Inter-Allied Services Department, to J. L. Froggatt, 6 July 1942. Report by Capt. J. K. McCarthy. N.G. 3015. I.S.D., 6 July 1942. 
Wessel never saw her parents again. ${ }^{36}$ Missions served a similar purpose in Papua and New Guinea as they did in Australia where young Indigenous girls of mixed descent were trained in domestic skills to work in white Australians' homes. ${ }^{37}$ Whereas in Australia, assimilation was the motivation for removing girls from families, in Papua and New Guinea, like in other colonies, 'the mission station became a threshold institution for transforming domesticity rooted in European gender and class roles into domesticity as controlling a colonized people'. ${ }^{38}$ The Sacred Heart Mission (MSC), like the Methodist Mission, separated boys and girls; the Daughters of Our Lady of the Sacred Heart, who arrived in New Britain in 1892, taught the girls to read, write and embroider. ${ }^{39}$ Also like the Methodist Mission, MSC added to its flock by removing children from their parents. As Stewart Firth has pointed out:

During the 1890s the authorities progressively permitted the MSC to take abandoned children from labour recruiting vessels, to seek them elsewhere from the Bismarck Archipelago and to use its own boats in the work of collection. ${ }^{40}$

In the first half of the twentieth century, the Australian administration in Papua and New Guinea granted concessions to missionaries to take Papuans and New Guineans abroad for purposes not outlined in the Native Labour Ordinance. For example, when it was discovered that the Native Labour Ordinance 1906 did not cater to the demands of missionaries, new legislation, the Removal of Natives Ordinance 1907, was introduced to allow an expatriate 'to take a native out of the Territory either permanently or temporarily' for a purpose not specified in the Native Labour Ordinance. ${ }^{41}$ The Removal of Natives Ordinance was repealed after two missionaries from the London Missionary Society (LMS) took Papuan attendants with them to Europe. According to one official, the Removal of Natives Ordinance had not been intended 'to supply cheap servants for passengers to Europe' and, importantly, its repeal would not 'in any way effect the practice of taking natives to Australia under the Native

36 NAA: A435, 1945/4/4736, John L. Froggatt, Port Moresby, to the Hon. E. J. Ward, Department of External Territories, 26 November 1946.

37 Firth, New Guinea under the Germans, 141.

38 McClintock, Imperial Leather, 35.

39 Venard, The History of the Daughters of Our Lady of the Sacred Heart in Papua New Guinea (Port Moresby, 1978), 75-99, cited in Firth, New Guinea under the Germans, 142.

40 Firth, New Guinea under the Germans, 142.

41 NAA: A1, 1909/13132, Papua. An Ordinance To Allow in Certain Cases the Removal of Natives from the Territory. Assented to by the Governor-General, 27 September 1907. 
Labour Ordinance. ${ }^{42}$ The repeal of the Removal of Natives Ordinance shows that the Australian Government exercised some regulation over missionaries; however, governance and Christian conversion were closely intertwined colonial processes. Missionaries not only 'civilised' Papuans and New Guineans through education and training, but also expanded their contact with Europeans. As European contact expanded, so did the reach of colonial governance, such as through a head tax and other coercive measures that gradually drew more and more Papuans and New Guineans into labouring for the colonial administration.

The Australian Government treated the missions leniently, exempting them from Papua's Native Labour Ordinance $1908 .{ }^{43}$ Earlier, missions had been consulted about how they wanted a section of the Native Labour Ordinance 1906 to be amended. ${ }^{44}$ In relation to the ordinance, Papua's acting administrator, John Hubert Plunkett Murray, wrote on 1 August 1908: 'For myself I was further influenced by ... the warning contained therein of the dangers of introducing legislation of which the Missions disapprove. ${ }^{45}$ Like a missionary education, labour was regarded as a civilising tool in Papua and New Guinea and the two were the main occasions in which Papuans, New Guineans and expatriates came into contact. It is no coincidence that the areas where the Methodist and Catholic missions were most active were also the most popular recruiting grounds for New Guinean women as labourers. From 1905 to 1907, 457 women were recruited from New Ireland to work in the Gazelle Peninsula and around Madang, and another 150 were recruited to work at other places in the colony and Samoa. In 1911, following a decline in the population, and based on the advice of medical experts, the official government gazette advised that all recruiting of women from southern New Ireland should cease. ${ }^{46}$

From the perspective of government, missionaries and labour recruiters, although often in competition with one another for the souls and/or bodies of Papuans and New Guineans, served a similar purpose in that

42 NAA: A1, 1909/13132, Repeal of The Removal of Natives Ordinance, 1907.

43 NAA: A1, 1909/13132, 'Papua. Bill to Amend the Native Labour Ordinance', memorandum, Atlee Hunt to Prime Minister, re Native Labour Ordinance, Papua, 10 September 1908.

44 NAA: 1909/13131, 'Papua. Bill to Amend the Native Labour Ordinance', memorandum, J. H. P. Murray to G. S., 25 July 1908.

45 NAA: 1909/13131, 'Papua. Bill to Amend the Native Labour Ordinance', memorandum, J. H. P. Murray, Acting Administrator, Government House, Port Moresby, Papua, to Minister of State for External Affairs, Melbourne, 1 August 1908.

46 Firth, New Guinea under the Germans, 125, 127. 
the Papuans and New Guineans they recruited were brought under the control, or at least the surveillance, of government. In some parts of New Guinea, indigenous people such as the Tolai utilised the knowledge they acquired through regular contact with Europeans to negotiate and resist European control over their lives. ${ }^{47}$ By the 1920 s, the education that missions provided to Papuans and New Guineans was regarded by some Australian expatriates as undermining white prestige, for teaching Papuans and New Guineans the tools of the colonisers closed the precarious gap that existed between the rulers and the ruled. ${ }^{48}$

Upon leaving the Methodist Mission where she was raised, Wessel worked as a domestic labourer for various 'prominent Australian people resident in Rabaul'. ${ }^{49}$ In 1934, she worked as a domestic in the home of John and Mary Froggatt who lived in Rabaul. ${ }^{50}$ John Froggatt worked as an entomologist for the New Guinea administration. ${ }^{51}$ In January 1938, Wessel travelled from New Guinea to Sydney with Mary Froggatt for the first time. From then on, she travelled back and forth between the east coast of Australia and the island of New Guinea. On 24 May 1939, Mary Froggatt arrived in Sydney for a six-month holiday and Wessel was permitted to land in Australia 'after the usual undertaking'. This included Mary Froggatt agreeing to be responsible for Wessel's 'maintenance and good behaviour' while in Australia and her assurance that Wessel would depart the country at the end of her stay..$^{52}$ A certificate of exemption was issued to Wessel for six months starting on 24 May 1939 and an additional six months was granted starting from 24 November $1939 .{ }^{53}$ On 22 January 1940, Wessel departed the port of Brisbane in Queensland for Papua. ${ }^{54}$

47 Firth, New Guinea under the Germans, 58-61, 63, 65, 80.

48 Wolfers, Race Relations and Colonial Rule, 2.

49 NAA: A435, 1945/4/4736, Alfred R. Gardner, General Secretary, Methodist Overseas Missions, to A. R. Peters, Acting Secretary, Department of Immigration, re 'Paula Wessel', 14 August 1945. Encl. signed J. L. Froggatt.

50 NAA: C123, 18325, memorandum, 'M.P.I. Section, Police Headquarters, Sydney'.

51 NAA: A367, C72805, Director to Controller, War Damage Commission, re 'National Security (War Damage to Property) Regulations: Claim by Paula WESSEL', 16 September 1947.

52 NAA: SP42/1, C1940/724, memorandum, Commonwealth of Australia, Customs and Excise Office, NSW, 'SUBJECT: Immigration Act 1901-1935: PAULA WESSEL, New Guinea Native (Half-caste) - Servant accompanying Mrs. Froggatt', signed C. F. Marks, A/g. Detective Inspector, 30 May 1939.

53 NAA: SP42/1, C1940/724, Commonwealth of Australia. Immigration Act 1901-1935. CERTIFICATE OF EXEMPTION. Date of Issue: 7 June 1939; Commonwealth of Australia. Immigration Act 1901-1935. CERTIFICATE OF EXEMPTION. Date of Issue: 21 September 1939. 54 NAA: SP42/1, C1940/724, memorandum, J. J. Barry A/g. Collector of Customs, NSW, to Secretary, Department of the Interior, Canberra, 12 February 1940. 


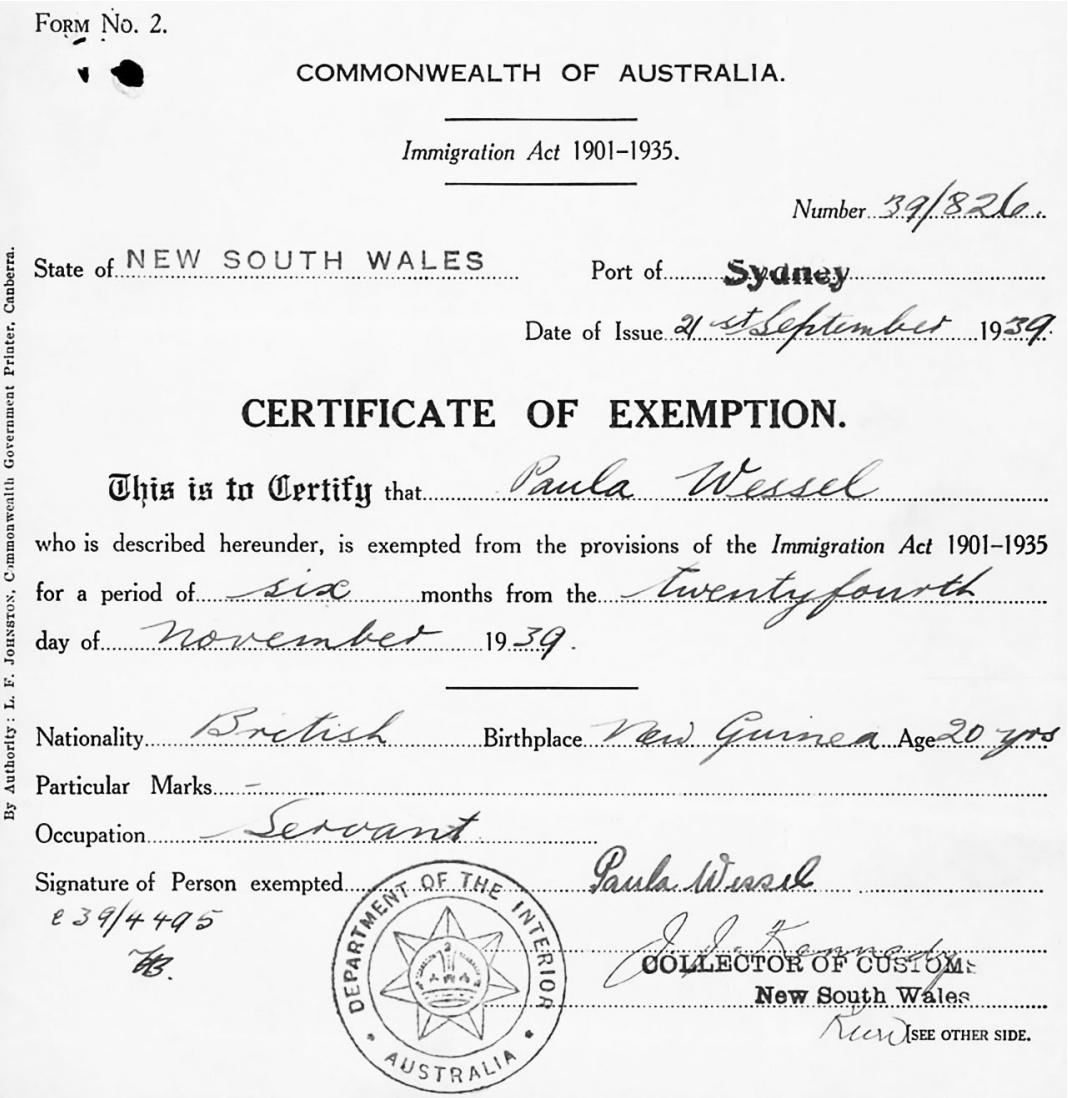

Figure 4.1: Paula Wessel's certificate of exemption.

Source: NAA: SP42/1, C1940/724, Certificate of Exemption.

Government correspondence and Australian newspapers from the 1940s indicate that Wessel was one among many Papuan and New Guinean domestics who travelled to Australia to work during the mid-twentieth century. It had become a common enough practice by the 1940s that Australians on the mainland contacted government officials with requests for Papuan and New Guinean domestic labourers. For example, on 4 November 1943, Reverend Mother Fitzpatrick of the Convent of the Sacred Heart, Stuartholme, South Port, wrote to Francis Michael Forde, minister of the army in Brisbane, requesting assistance with obtaining 'the services of three Fuzzy Wuzzy girls'. ${ }^{55}$ The letter was received by Australian officials with little surprise. After making some enquiries, Edward John

55 NAA: A518, E840/1/1, M. Fitzpatrick, Convent of the Sacred Heart, to F. M. Forde, Minister for Army, 4 November 1943. 
Ward of the Department of External Territories replied that he was unable to find any 'New Guinea native girls' in Australia who were able to work for Fitzpatrick. ${ }^{56}$ The casual tone of the letters, and the mutual understanding that 'Fuzzy Wuzzy girls' meant New Guineans, suggests the existence of an established routine in recruiting and employing Papuan and New Guinean domestic labourers. Newspaper reports in Australia about the arrival of a New Guinean domestic worker, Nekiwaia, in December 1948, aroused a moderate level of interest, further indicating that there was widespread community awareness and acceptance of New Guinean domestic labourers in Australia after the Pacific War. ${ }^{57}$

World War II (WWII) represents a significant moment in the history of Papuan and New Guinean domestic workers in Australia. The war, which began in Europe in 1939, reached the Pacific in 1941. In December that year, as Japan's invasion of the island of New Guinea appeared imminent, white women and children were evacuated from Papua and New Guinea. While the evacuation only officially applied to white women and children, some Papuan and New Guinean domestic workers accompanied their employers. Wessel was one of these workers, travelling to Australia with her employer, Mary Froggatt, as part of the evacuation in December 1941. ${ }^{58}$ Having a German father, Wessel was registered as an 'enemy alien'. When she arrived in Sydney on 31 December 1941, she was required to sign a 'Personal Statement of Alien Passenger' form. ${ }^{59}$ A few months after Wessel's arrival, in March 1942, Wessel's residence at Wentworth Falls was searched by the police for subversive or prohibited possessions. The police questioned Mary Froggatt, who assured them that Wessel was loyally British. ${ }^{60}$ While in Rabaul, Mary Froggatt had applied for Wessel to be removed from the list of enemy aliens, but approval had not been given. ${ }^{61}$ Four months after the police searched Wessel's premises, John Lewis Froggatt employed a solicitor, Mervyn Finlay, to try and have Wessal's name removed the list of enemy aliens. According to Finlay, his

56 NAA: A518, E840/1/1, E. J. Ward to Mother Fitzpatrick, Convent of the Sacred Heart, 11 January 1944; E. J. Ward, Minister for External Territories, to Rev. Mother Fitzpatrick, Convent of the Sacred Heart, 18 January 1944.

57 'SUCH WONDERS TO SEE: Sixteen-Years-Old Nekiwaia, of Ferguson Island, Who Came to Town Today, for the First Time Saw City Buildings, Trams, Modern Cars and Other Adjuncts of Civilisation', Brisbane Telegraph, 15 December 1948, 2.

58 NAA: A435, 1945/4/4736, John L. Froggatt, Port Moresby, to E. J. Ward, Department of External Territories, Canberra, 26 November 1946.

59 NAA: A12508, 21/4641, Commonwealth of Australia. Immigration Act 1901-1925. Personal Declaration by Alien Passenger.

60 NAA: C123, 18325, memorandum, 'M.P.I. Section, Police Headquarters, Sydney'.

61 NAA: C123, 18325, Deputy Director of Security for New South Wales to Director General of Security, Canberra, re 'PAULA WESSEL, 13 March 1943. 
client felt that it was unfair to Wessel, and embarrassing for him and his wife, to have his servant listed as an enemy alien. ${ }^{62}$ John Froggatt also contacted various Australians who had worked in Papua, including John Wear Burton, general secretary of the Methodist Overseas Mission, and Daisy Coltheart, from the girls home at Cootamundra, for their assistance in having Wessel's name removed from the list of enemy aliens.

In 1943, John Froggatt applied on Wessel's behalf for her to travel from Campbelltown, where she lived, to 58 Springfield Road, Killara, Sydney, to visit her friend Johanna Lehman, a New Guinean domestic servant who worked for Mrs Coote. ${ }^{63}$ Like Wessel, Lehman was listed as an enemy alien. ${ }^{64}$ John Froggatt also requested permission for Wessel to travel to Sydney every fortnight to go shopping and to the picture shows at Campbelltown. Similar applications had been made on behalf of Johanna Lehman and Johanna Lieberang, another New Guinean domestic servant in Sydney. According to the director general of security, all three women were 'illegitimate children of mothers of New Guinea'. They had all been raised in missions and were described as 'definitely proBritish in both their outlook and associations'. Lehmann and Lieberang were free to leave their suburb to go shopping and to church as long as they remained within the bounds of metropolitan Sydney. ${ }^{65}$ After John Froggatt's application, Wessel was also exempted from compliance with the provisions of Regulation 17(1) of the National Security (Aliens Control) Regulations, which meant she was no longer required to obtain written permission from an aliens registration officer to visit Killara and Sydney. ${ }^{66}$ Wessel was also granted permission to travel freely within her own district, including to visit picture shows. ${ }^{67}$

62 NAA: C123, 18325, Mervyn Finlay, Solicitor, Newlands House, to Secretary, Department of the Interior, 17 July 1942.

63 NAA: C123, 18325, memorandum, Director General of Security to Deputy Director of Security, Sydney, 'SUBJECT: PAULA WESSEL', 10 March 1943. See also John L. Froggatt to Rev. J. W. Burton, Methodist Overseas Mission, 5 April 1943.

64 NAA: C123, 18325, memorandum, Director General of Security to Deputy Director of Security, Sydney, 'SUBJECT: PAULA WESSEL', 10 March 1943. See also, memorandum, Deputy Director of Security for New South Wales to Commissioner of Police, Sydney, 'SUBJECT: Paula WESSEL - German - Cooper Research Station, St. Helens Park, Campbelltown. Question of Travel', 27 May 1943.

65 NAA: C123, 18325, memorandum, Director General of Security to Deputy Director of Security, Sydney, 'SUBJECT: PAULA WESSEL', 10 March 1943.

66 NAA: C123, 18325, 'NATIONAL SECURITY ACT 1939-1940. NATIONAL SECURITY (ALIENS CONTROL) REGULATIONS. REGULATION 4A-(2) ORDER', signed, Deputy Director of Security for New South Wales, Sydney, 27 May 1943.

67 NAA: C123, 18325, Director-General of Security to Dr Burton, re 'PAULA WESSEL', 20 March 1943; Deputy Director of Security for New South Wales to Commissioner of Police, Sydney, 25 March 1943. 
PERSONAL STATEMENT AND DECLARATION.

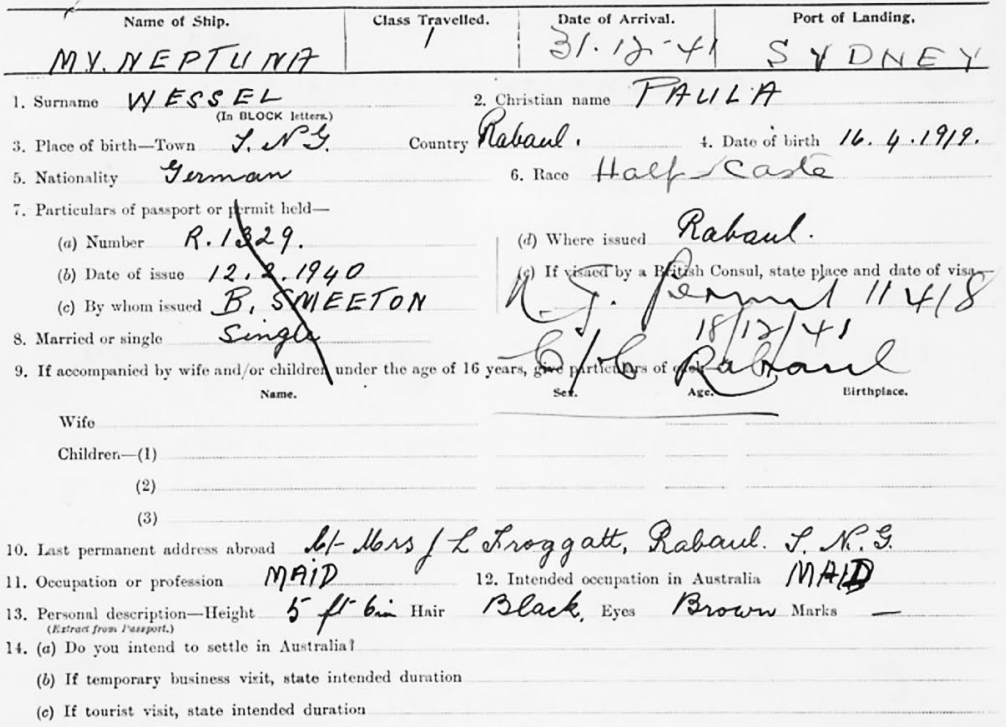

15. If you have $\left\{\begin{array}{l}(a) \text { relatieres } \\ (b) \text { friends }\end{array}\right\}$ in Australia, givo names and addresses of two-

(a) Relatives-(1) Name. Adsress.

(2) (1) hus G. E. Hall 80 R-Sages Gos! Dummogne

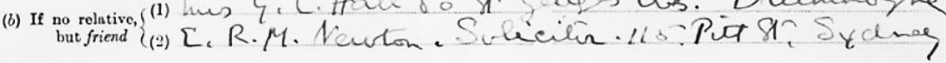
16. Proposed permanent address in Australia

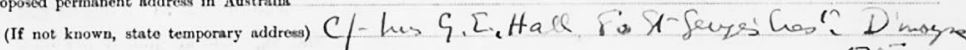
17. What amount of money your own bona fide property can you produce? (If more than 2100 , state fl00.) 2.55 .

If less than $\mathcal{L} 40$, state whether maintenance or employment has been guaranteed by any resident of Australia; and, if so, give name and address of such person thrs f. L. Sroggatt,

18. Aro you, and any dependants acoompanying you, in sound mental and physical health? If not, stute disability

19. Have you had any training - (a) Navy

(b) Army

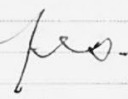

(c) Air Force

In what countiy

20. Aro you a Reservist? $N O$

21. Have you previously resided in Australia! yES

date of leaving Australia

If so, state in what unit

I hereby declare that I understand the above questions, and that the answers given by me to the questions are true and correct. I yndertake that while in Australia I will faithfully observe and obey the laws of Australia.

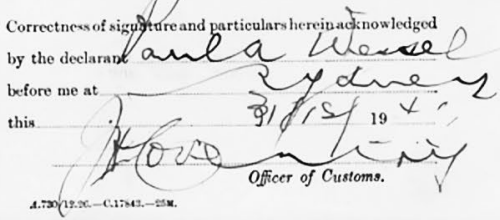

signature Saula Heceel.

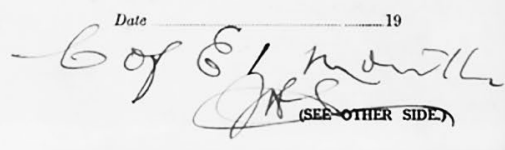

Figure 4.2: Personal statement by 'Alien Passenger' signed by Paula Wessel.

Source: NAA: A367, C72805, Commonwealth of Australia. Personal Statement by Alien Passenger. 
After WWII, the Froggatts applied to have Wessel naturalised. However, in May 1946, the Department of Immigration concluded that, since it was 'contrary to existing policy to naturalize persons of coloured race', and 'as Paula Wessel is a coloured person', she was not eligible. ${ }^{68}$ On 26 November 1946, John Froggatt made a direct appeal to Ward regarding Wessel's case. He explained that his wife 'has had this half-caste girl companion with her for nearly thirteen years, and we treat her as one of our family', but to no avail. ${ }^{69}$ In January 1947, Wessel's application for naturalisation was again rejected. ${ }^{70}$ On 2 June 1948, at the Salvation Army Headquarters, Sydney, Wessel married Arthur C. Thompson of Campbelltown. The couple were expecting a baby in July. Two days after the marriage, John Froggatt notified the Sydney office of the Department of External Territories of the marriage. A little over a fortnight later, Froggatt received a letter from the Department of Immigration informing him that Wessel's certificate of exemption would not be extended, and that Wessel was required to depart Australia 'by the first available vessel'. ${ }^{71}$ After almost a decade of travelling to and from Australia, this was the first time that Wessel had been denied a certificate of exemption.

Wessel's employers regularly described her as a member of their family. When Wessel's residence was searched in March 1942, Mary Froggatt described her 'as a friend and companion rather than as an employee'. ${ }^{72}$ At other times, Wessel was depicted by the Froggatts as their child; the Froggatts claimed that they could represent her desires and opinions as they knew her so well. For example, John Froggatt, when applying for British naturalisation on Wessel's behalf, wrote that:

We have seen her grow up in our home, and have thus been able to understand and appreciate her outlook and feelings, and therefore know how keenly she desires to obtain her British Naturalisation. ${ }^{73}$

68 NAA: A435, 1945/4/4736, memorandum, 'Paula WESSEL - Half-Caste - German father and New Guinea Native Mother', Department of Immigration, 23 May 1946.

69 NAA: A435, 1945/4/4736, John L. Froggatt, Port Moresby, Papua, to E. J. Ward, Department of External Territories, Canberra, 26 November 1946.

70 NAA: A435, 1945/4/4736, memorandum, T. H. E. Heyes, Secretary, to Secretary, Department of External Territories, Canberra, re 'Paula Wessel - Naturalization', 13 January 1947.

71 NAA: A435, 1945/4/4736, C. F. Marks, Commonwealth Migration Officer, Department of Immigration, Sydney, to L. J. Froggatt, The Cooper Research Station St. Helens Park, Campbelltown, re 'PAULA WESSEL', 15 June 1948.

72 NAA: C123, 18325, memorandum, 'M.P.I. Section, Police Headquarters, Sydney'.

73 NAA: A435, 1945/4/4736, John L. Froggatt, Port Moresby, Papua, to E. J. Ward, Department of External Territories, Canberra, 26 November 1946. 
While Papuan and New Guinean domestics worker did, at times, build amicable relationships with their employers, as histories of Aboriginal domestic workers and their white female employers have shown, 'a fundamental inequality prevailed'. ${ }^{74}$ This underlying inequality was evident in the language the Froggatts used to describe Wessel. Mary Froggatt, writing to an Australian official about Wessel, commented: 'a half-caste's life is a sad thing in the Territory'. ${ }^{75}$ Thus, Papuan and New Guinean domestic workers, even when they were described as part of the family by employers, could just as easily be represented as racialised subjects and thereby excluded from the family group. Compounding this, all the correspondence about Wessel's travel to Australia, including applications for extension of her stay, were conducted on her behalf by her employers, making her entirely dependent on their support.

It seems that Wessel had limited capacity to express her own opinions and needs. There are no letters from her among the correspondence between the Froggatts and Australian officials. However, her signature at the bottom of one form, and reports on her actions, provide glimpses into the subtle, yet creative, ways she negotiated her situation, as well as the structural constraints she encountered in doing so. During her time in Australia, Wessel developed relative autonomy and increasingly expressed her opinions, even when they differed from her employers. For example, at the beginning of 1946, the Froggatts decided to return to Port Moresby and leave Wessel in Australia, as they believed this would aid her application for British naturalisation; the Froggatts had been told that Wessel needed to be a resident in Australia for five years for her application to be successful. The Froggatts arranged alternative employment for Wessel at the Infants Home, Henry Street, Ashfield. She began working there on 21 February 1946. At the Infants Home, she had 'a delightful room to herself' and was on a wage of 30/- per week plus keep. As part of the nursing staff, she wore a uniform and cap, was not required to undertake any domestic duties and had two days off per week. ${ }^{76}$ Prior to starting work, Wessel 'seemed enthusiastic about going to Ashfield'; however, when she was interviewed by a government official, Mr Downing, on 19 March, she explained that, while she was being well treated, she would prefer to move to the Campbelltown Cripple Home,

74 Tonkinson, 'Sisterhood or Aboriginal Servitude?', 29.

75 NAA: A518, E840/1/1, P. Froggatt, Macquarie Club, to Mr Downing, n.d.

76 NAA: A518, E840/1/1, P. Froggatt, Campbelltown, to Downing, 4 February 1946; P. Froggatt, Macquarie Club, to Downing, n.d. 
where there was 'less work, and more freedom'. She was adamant that she did not wish to return to New Guinea. Subsequently, Australian officials decided that Wessel had 'been getting a little too much attention' and was 'in need of some control'. Therefore, it was recommended that she remain at Ashfield. ${ }^{77}$ This response to Wessel's request to change employment shows that the government prioritised control over the wishes of Papua and New Guinean domestics. ${ }^{78}$

Mary and John Froggatt's actions in seeking naturalisation for Wessel indicate that they cared for Wessel and her wellbeing. John Froggatt cited other actions, such as arranging an apartment, alternative employment and taking out an annuity for Wessel, as evidence that his and his wife's concern for Wessel was sincere. However, the relationship between the Froggatts and Wessel, like that between all employers and domestics, was dependent on the will of the employer.

While the ambiguous position of Papuan and New Guinean domestic labourers in Australians' homes was often precarious, this section has explored through the story of Paula Wessel how this ambiguity was utilised by some domestics to their advantage. The following section, which examines the experiences of other Papuan and New Guinean domestic labourers, such as Susan Hari, Pouna and Lavu, Annie Lundin, Celestine Blanco, Blanche Burfitt and Cecilia Phlug (or Pflug), reveals the vulnerability of domestic workers in Australia and some of the complex ways they negotiated government surveillance and control.

\section{'Certainly the Girl's Work Is Not Arduous': Government Surveillance and Control}

The case of a Papuan domestic worker in Australia in the 1940s shows how the position of a domestic could change based on the will of their employer. Susan Hari was born in 1924 in Isuleilei along the south coast of Papua's Fyfe Bay. A teenager when she disembarked in Australia on 2 December 1941, Hari arrived under the 'guardianship' of 'Mrs Fisher' who had four children aged between six and ten. Mrs Fisher's husband

77 NAA: A518, E840/1/1, memorandum, C. E. Leake, Officer in Charge, Department of External Territories, Sydney, to Secretary, Canberra, re 'PAULA WESSEL', 2 April 1946.

78 New Zealand officials also sought to control Cook Islander domestic workers' increasing autonomy in New Zealand under the guise of welfare. See Anderson, 'Distant Daughters', 285. 
was in the forces in New Guinea. A government report from an inspection of Hari's workplace noted that she 'enjoyed the same privileges as the family'; this was despite Hari not being allowed to leave her employer's house unaccompanied, not having set working hours and having her pay withheld while her contract was finalised. ${ }^{79}$ While working in Australia, Hari became pregnant and gave birth to a son, James, at the Salvation Army Home, Marrickville, in July 1944. James's paternity was recorded as 'unknown' ${ }^{80}$ Fisher attempted to have the baby cared for by the Sydney Rescue Work Society or a similar LMS affiliate. She also applied for a maternity bonus and child endowment for Hari; however, since Hari had been in Australia for less than five years and was a 'full native', she was not eligible. ${ }^{81}$ In January 1945, Hari was still at Marrickville due to Fisher having 'lost interest in the girl'. ${ }^{82}$ By August that year, Hari and James were living with Fisher; however, at the government's recommendation, they departed Sydney on 31 August $1945 . .^{83}$ Henry Leonard Hurst, a representative from the LMS, confirmed that Hari would be returned to Papua 'in the charge of some woman missionary' and that she would be cared for by the LMS once she was back in Papua. ${ }^{84}$ Hari's experience is testament to the vulnerability of Papuan and New Guinean domestic workers in Australia. Often, such women were not only without parents or family in Papua and New Guinea, but also lacked the support of community, and their experience of work in Australia left them vulnerable to physical abuse. As labourers on the Australian mainland, Papuan and New Guinean domestics were reliant on Australian officials' arbitrary protection.

On 9 March 1943, C. E. Leake, the officer in charge of the Department of External Territories, Sydney, wrote to the assistant secretary of the same department in Canberra about Papuan and New Guinean 'half caste and native girls in New South Wales who have been brought south

79 NAA: A518, E840/1/1, 'REPORT ON NEW GUINEA (MAIDS) IN AUSTRALIA, HARI, Susan, Papuan Native Girl', Department of External Territories, Sydney, Report No. 1, 14 June 1943. 80 NAA: A518, 822/2/603, memorandum, J. R. Halligan, Secretary, Department of External Territories, Canberra, to Director of Research \& Civil Affairs, Headquarters, Victoria Barracks, Melbourne, 9 August 1945 (including attachments).

81 NAA: A518, 822/2/603, extract from Department of External Territories Sydney Office memorandum, 1 August 1945.

82 NAA: A518, 822/2/603, 'HARI, Susan', 7 August 1945.

83 NAA: A518, E840/1/1, memorandum, J. R. Halligan, Secretary, Department of External Territories, to Acting Secretary, Department of Immigration, Canberra, 30 August 1945.

84 NAA: A518, E840/1/1, Hurst London Missionary Society, Sydney, to Mr Halligan, Department of External Territories, Canberra, 7 March 1944. 
... concerning whom we have no official knowledge'. Leake's letter had been prompted by 'several indirect complaints by these domestics' and he wished to know whether there were any conditions 'for their keep, wages, hours of recreation, etc'. ${ }^{85}$ A list of seven Papuan and New Guinean women's names was attached to the letter. ${ }^{86}$ In reply, J. Brack requested that the women be visited by an official from the Sydney branch as soon as possible, and then 'at quarterly intervals' to obtain information on their working conditions, wages and welfare. He also requested that 'complaints should be carefully investigated'. As far as Brack knew, there were no specific conditions of employment for Papuan and New Guinean women in Australia; instead, the women worked under conditions agreed upon with their employers before arriving in Australia. ${ }^{87}$ Although this response has the appearance of being motivated by concern for the welfare of Papuan and New Guinean domestic workers, closer scrutiny reveals that Australian officials employed surveillance to control these women.

The process of investigating the complaints included conducting interviews with the Papuan and New Guinean women in front of their employers, which meant that they had limited opportunity to express their complaints without fear of reprisal. Two Papuan and New Guinean domestic workers, Pouna and Lavu, who were visited and interviewed by Downing in front of their employer later walked to Downing's office to voice their discontent in private. ${ }^{88}$ Such complaints were often dismissed by Australian officials or retracted by the domestic worker. For example, a report on domestic worker Annie Lundin explained that she:

Was restless and wanted to go to other employment where she could earn more money but is now contented again, and realises that she is really well off, and among good people. ${ }^{89}$

Celestine Blanco made numerous attempts to leave her place of employment, Prince Henry Hospital, and seek work at a factory near Glebe Point, but the hospital authorities refused to release her. The officer

85 NAA: A518, E840/1/1, memorandum, C. E. Leake, Officer-in-Charge, Department of External Territories, Sydney, to Assistant Secretary, Department of External Territories, Canberra, 9 March 1943. 86 The Papuan and New Guinean women listed included Emma Lehmann, Cecilia Phlug, Johanna Lieverens (or Lieverang), Paula Wessel, Annie Lundin, Luise Taligatus and Susan Hari.

87 NAA: A518, E840/1/1, memorandum, J. Brack, for Assistant Secretary, Canberra, to Officer-inCharge, Sydney Office, re 'New Guinea and Papuan Half-castes in Australia', 6 May 1943.

88 See: NAA: A518, HH112/1 PART 2; NAA: A518, HH112/1 PART 3.

89 NAA: A518, E840/1/1, memorandum, Department of External Territories, Sydney, to Secretary, Canberra, re 'HALF CASTE AND NATIVE NEW GUINEA GIRLS IN AUSTRALIA', 17 January 1945. 
who conducted the report on Blanco did not consider her situation detrimental to her wellbeing and advised her to remain at the hospital. ${ }^{90}$ The department's response to these Papuan and New Guinean domestic workers' complaints, when placed alongside the reports of another domestic worker, Cecilia Phlug, illuminate the creative and calculated ways such women both survived and escaped difficult working conditions in Australia.

New Guinean Cecilia Phlug (or Pflug) arrived in Sydney at the end of December 1941 in the company of her employer H. G. Woolcott. ${ }^{11}$ Subsequently, Phlug was 'handed over' to Woolcott's sister, Edna McLean, with the approval of T. McAdam of Rabaul Customs. ${ }^{92}$ From 30 December 1941 to 23 November 1943, Phlug was employed by Edna McLean in Warrawee, a suburb on Sydney's affluent upper north shore. ${ }^{93}$ On 24 November 1943, after almost two years of working in the McLean household, Edna McLean telephoned the Department of External Territories and reported that she had had 'further trouble' with her employee, Phlug. McLean then sent Phlug to her mother-in-law's house at Manly. Phlug remained there for several weeks until McLean's motherin-law asked for her to be removed following 'further disobedience'. In the wake of these complaints, a department official interviewed Phlug, who requested to leave her current position. The department heeded Phlug's request and found her a job at the Prince Henry Hospital. Thereafter, her behaviour and movements were closely monitored by Australian officials until she was eventually repatriated..$^{94}$

90 NAA: A518, E840/1/1, memorandum, C. E. Leake, Officer-in-Charge, Department of External Territories, Sydney, to Assistant Secretary, Canberra, re 'Miss Celestine BLANCO - Report No. 2', 22 November 1943.

91 NAA: A518, E840/1/1, memorandum, Acting Secretary, Department of Immigration, Canberra, to Secretary, Department of External Territories, Canberra, re 'Cecilia Phlug (or Pflug) Half-Caste New Guinea Native of German Nationality under exemption’, 4 February 1946.

92 NAA: A518, E 840/1/1, 'List of Papuan and New Guinean Female Natives \& Half ... Officially Recorded by this Officer'.

93 NAA: A518, E840/1/1, memorandum, J. R. Halligan, Secretary, to Officer-in-Charge, Sydney, re 'Cecelia Pflugg: Half-caste (New Guinea)', 29 August 1946.

94 NAA: A518, E840/1/1, memorandum, Acting Secretary, Department of Immigration, Canberra, to Secretary, Department of External Territories, Canberra, re 'Cecilia Phlug (or Pflug) - Half-Caste New Guinea Native of German Nationality under exemption’, 4 February 1946; 'List of Papuan \& New Guinean Female Natives \& Half ... Officially Recorded by this Officer'; memorandum, J. R. Halligan, Secretary, to Officer-in-Charge, Sydney, re 'Cecelia Pflugg: Half-caste (New Guinea)', 29 August 1946; memorandum, J. Brack, Acting Officer in Charge, Department of External Territories, Sydney, to Assistant Secretary, Canberra, re 'CECILIA PHLUGG', 15 December 1943; memorandum, C. E. Leake, Officer-in-Charge, Department of External Territories, Sydney, to Assistant Secretary, Canberra, re 'Cecilia Phlug - New Guinea Half Caste', 10 January 1944. 
As a result of her 'disobedience'-or, rather, the complaints of her white employers-Phlug was subject to government surveillance. By contrast, the complaints of Papuan and New Guinean domestic labourers, like those of Pouna, Lavu, Lundin and Blanco, were largely dismissed. This was in part due to Australian officials not regarding Papuan and New Guinean domestics' labour as real work. Papuan and New Guinean domestics' wages were often described by employers and Australian officials as 'pocket money' and many employers were described as 'guardians. ${ }^{95}$ As Leake wrote on 25 June 1943:

There is some differences in the pocket money being paid to these maids by their guardians, but this is not great, and as all express contentment, and are being well cared for, the reports may be considered as very satisfactory. ${ }^{96}$

Australian officials' disregard for domestic labour contributed to the already vulnerable position of domestic workers and increased the likelihood of exploitation, as employers were not held to account by Australian officials or given any guidelines on working hours, wages and tasks. For example, Papuan domestic worker Blanche Burfitt was paid $£ 1$ per month in Papua; however, in Australia her employer was unable to afford the cost of her wages and instead gave her 'pocket money' and paid for her expenses.

Domestic workers' working tasks and hours were loosely described by employers and officials as 'general household duties' and 'an ordinary household day'. ${ }^{97}$ Domestic worker Annie Lundin's employer, Mrs Hawnt, described Lundin's jobs as looking after her daughter and her daughter's three children and 'helping generally', leading one government official to conclude that: 'Certainly the girl's work is not arduous. ${ }^{\text {'98 }}$ This is in stark contrast to other descriptions of domestic work in Australia.

95 NAA: A518, E840/1/1, memorandum, C. E. Leake, Officer-in-Charge, Department of External Territories, Sydney, to Assistant Secretary, Canberra, re 'New Guinea \& Papuan Half Castes in Australia', 25 June 1943.

96 NAA: A518, E840/1/1, memorandum, C. E. Leake, Officer-in-Charge, Department of External Territories, Sydney, to Assistant Secretary, Canberra, re 'New Guinea \& Papuan Half Castes in Australia', 25 June 1943.

97 For example, NAA: A518, E840/1/1, 'REPORT ON NEW GUINEA FEMALES (MAIDS) IN AUSTRALIA. LIEVRANG, Johanna Half Caste German (Single)', Department of External Territories, Sydney Office, Report No. 1 17/6/43.

98 NAA A518, E840/1/1, memorandum, A. J. Gaskin, Department of External Territories, Sydney, to Secretary, Department of External Territories, Canberra, re 'HALF CASTES AND NATIVE GIRLS IN AUSTRALIA', 28 July 1944. 
Historian Shirleene Robinson has described the work of Aboriginal child domestics in Queensland as 'physically laborious, emotionally exhausting and low paying. ${ }^{99}$ Further, as Alice Wedega's personal account of working in Australia attests, Papuan and New Guinean domestic workers were also regularly subject to abuse by their employers.

Papuan and New Guinean domestic workers who expressed discontent and demanded improvements in their conditions of work caught the attention of Australian officials; these women came under close government supervision and their stories have made it into the archives. In other cases, the mere presence of Papuan and New Guinean domestics in Australia was enough to attract surveillance. The regulation of Papuan and New Guinean domestic workers was extensive; however, there is evidence that not all Papuan and New Guinean domestic workers were watched by government. For example, a death notice in The Sydney Morning Herald in 1946 reported that Nati, a 'native of New Britain, loved and faithful friend of the family for over 50 years', had passed away at Wollstonecraft. Nati had travelled to Australia 'many years ago' with the Reverend Rickard, a former member of the Methodist Missionary Society, but she was unknown to government. ${ }^{100}$ The stories told in this chapter have only scratched the surface of the history of Papuan and New Guinean domestic workers in Australia in the first half of the twentieth century. The regulations catering to the travel of Papuan and New Guinean domestic workers to Australia, and evidence that this was a widely accepted practice, indicates that a more extensive labour trade in Papuan and New Guinean domestics to Australia existed than has previously been imagined.

\section{Conclusion}

This chapter opened with the story of Alice Wedega who, as a young woman, travelled to Australia to work as a domestic labourer. Her story, like the stories of other Papuan and New Guinean domestic workers, illustrates how intersecting forces of coloniality, such as having a mission education and government regulation, affected her experience of working

99 Robinson, Something Like Slavery?, 162, 163.

100 NAA: A518, E840/1/1, memorandum, Major for DA\&QMG (ANGAU), HQ Eight Military, District Rabaul CA70/6 Australian Military Forces, to Secretary, Department of External Territories, Canberra, re 'NEW GUINEA NATIVES IN AUSTRALIA, NATI (Deceased)', 26 March 1946. 
abroad. When Wedega returned to Papua and relayed her experience to her friends, she influenced how other Papuans viewed work and life in Australia. Wedega's criticism of Australians, based on her newly acquired knowledge of them, may not have been transformative for Australia's administration in Papua, but her criticisms nevertheless had the effect of subtly undermining Australian authority.

The stories of Papuan and New Guinean domestic workers outlined in this chapter were accessed through the lens of the government officials who tracked their travels to and from Australia, movements around Australia, and everyday working and personal lives. The extent of Australia's surveillance of Papuan and New Guinean domestics, and official view that such workers needed to be controlled and disciplined through surveillance, regulation and even repatriation, point to the ways in which these women, through their mere presence in the homes of Australian citizens, unsettled Australian officials.

By placing the stories of individual Papuan and New Guinean domestic workers in the foreground, this chapter has provided a glimpse of Papuan and New Guinean women's experiences of labour in Australia during the first half of the twentieth century. Their stories show that the relationship between employers and domestics was undefined and exploitative, as workers were left vulnerable to the will of employers and without the protection of officials. Yet, despite these circumstances, some Papuan and New Guinean domestics, like Paula Wessel, exercised autonomy. Wessel and other domestic labourers' actions do not appear significant unless they are properly considered in terms of their colonial context- they were simply women working as domestic labourers who visited friends, went shopping and attended the cinema on their days off. However, placed within the context of Papua and New Guinea, their everyday actions were exceptional. Not only did these non-white women travel to Australia and work in white Australian citizens' homes during the era of 'White Australia', they travelled around the suburbs of Sydney, married Australian citizens and had children. Even more extraordinary is the fact that they did this while regarded as 'enemy aliens'. Although they were required to obtain a permit to visit Sydney, their ability to do so and subsequent exercise of autonomy and freedom of mobility made them vastly different to their peers in Papua and New Guinea. The strict segregation between Papuans and New Guineans and Australian expatriates in the towns of Port Moresby and Rabaul continued long after the Pacific War. Australia 
did not repeal its curfew laws in Papua and New Guinea until 1959. ${ }^{101}$ This makes the stories of Papuan and New Guinean domestic workers valuable in their own right (as little-known historical subjects) and vital in terms of their collective role as important actors in colonial relations between Australia and Papua and New Guinea.

\section{Bibliography}

\section{Primary Sources}

NAA: BP342/1, 9115/327/1903.

NAA: A367, C72805.

NAA: A435, 1945/4/4736.

NAA: A12508, 21/4641.

NAA: $1909 / 13131$.

NAA: A1, 1909/13132.

NAA: SP42/1, C1940/724.

NAA: C123, 18325.

NAA: A518, E840/1/1.

NAA: A518, HH112/1 PART 2.

NAA: A518, HH112/1 PART 3.

NAA: A518, 822/2/603.

Papua Act 1905, Federal Register of Legislation, accessed 31 May 2017, www. legislation.gov.au/Details/C1905A00009.

\section{Secondary Sources}

Anderson, Rosemary. 'Distant Daughters'. The Journal of Pacific History 48, no. 3 (2013), 267-85. doi.org/10.1080/00223344.2013.823008.

Austin, Tony. 'Cecil Cook, Scientific Thought and 'Half-Castes' in the Northern Territory 1927-1939'. Aboriginal History 14, no. 1 (1990): 104-22.

Banivanua Mar, Tracey. Decolonisation and the Pacific: Indigenous Globalisation and the Ends of Empire. Cambridge, United Kingdom: Cambridge University Press, 2016.

101 Wolfers, Race Relations and Colonial Rule, 45. 
- Violence and Colonial Dialogue: The Australian-Pacific Indentured Labor Trade. Honolulu: University of Hawai'i Press, 2007.

Davies, Lucy. 'The Movement of Papuan Women into Australia as Domestic Servants during the 1940 s and 1950s'. Honours Thesis, La Trobe University, 2011.

Denoon, Donald. 'Miss Tessie Lavau’s Request'. Meanjin 62, no. 3 (2003): 136-43.

- A Trial Separation: Australia and the Decolonisation of Papua New Guinea. Canberra: ANU E Press, 2012. doi.org/10.22459/TS.05.2012.

Dickson-Waiko, Anne. 'Women, Nation and Decolonisation in Papua New Guinea'. The Journal of Pacific History 48, no. 2 (2013): 177-93. doi.org/ 10.1080/00223344.2013.802844.

Firth, Stewart. New Guinea under the Germans. Carlton: Melbourne University Press, 1983.

Haskins, Victoria. 'From the Centre to the City: Modernity, Mobility and MixedDescent Aboriginal Domestic Workers from Central Australia'. Women's History Review 18, no. 1 (2009): 155-75. doi.org/10.1080/09612020802608108.

Haskins, Victoria and Anne Scrimgeour. "'Strike Strike, We Strike”: Making Aboriginal Domestic Labor Visible in the Pilbara Pastoral Workers' Strike, Western Australia, 1946-1952'. International Labor and Working-Class History, 88 (2015): 87-108. doi.org/10.1017/S0147547915000228.

Higman, B.W. 'Testing the Boundaries of White Australia: Domestic Servants and Immigration Policy, 1901-45'. Immigrants and Minorities 22, no. 1 (2003): 1-21. doi.org/10.1080/02619288.2003.9975051.

Mair, Lucy Philip. Australia in New Guinea. Carlton, Victoria: Melbourne University Press, 1970.

Martínez, Julia, Claire Lowrie, Frances Steel and Victoria Haskins. Colonialism and Male Domestic Service across the Asia Pacific. eBook: Bloomsbury Academic, 2019.

McClintock, Anne. Imperial Leather: Race, Gender and Sexuality in the Colonial Contest. New York: Routledge, 1995.

McGinn, Ian. 'Commonwealth Control of Non-Indigenous and Indigenous Relations and Mixed-Descent People in the Northern Territory, 1911-1939'. Journal of Northern Territory History 23 (2012): 25-41.

Mercer, Patricia. White Australia Defied: Pacific Islander Settlement in North Queensland. Townsville: James Cook University, 1995. 
Robinson, Shirleene. Something Like Slavery? Queensland's Aboriginal Child Workers, 1842-1945. North Melbourne: Australian Scholarly Publishing, 2008.

Russell, Lynette. Roving Mariners: Australian Aboriginal Whalers and Sealers in the Southern Oceans, 1790-1870. Ithaca: State University of New York Press, 2012.

Stoler, Ann Laura. Carnal Knowledge and Imperial Power: Race and the Intimate in Colonial Rule. Berkeley: University of California Press, 2010.

Tavan, Gwenda. The Long, Slow Death of White Australia. Carlton North, Victoria: Scribe, 2005.

Tonkinson, Myrna. 'Sisterhood or Aboriginal Servitude? Black Women and White Women on the Australia Frontier'. Aboriginal History 12 (1988): 27-39.

van der Veur, Paul W. Search for New Guinea's Boundaries: From Torres Strait to the Pacific. Canberra: Australian National University Press, 1966. doi.org/ 10.1007/978-94-015-3620-2.

Waiko, John Dademo. A Short History of Papua New Guinea. South Melbourne, Victoria: Oxford University Press, 2007, 2013. [2nd edition.]

Wedega, Alice. Listen, My Country. Sydney, NSW: Pacific Publications, 1981.

Wolfers, Edward. Race Relations and Colonial Rule in Papua New Guinea. New South Wales: Australian and New Zealand Book Company, 1975.

\section{Newspapers}

Brisbane Telegraph 
This text is taken from Labour Lines and Colonial Power: Indigenous and Pacific Islander Labour Mobility in Australia, edited by Victoria Stead and Jon Altman, published 2019 by ANU Press, The Australian National University, Canberra, Australia.

doi.org/10.22459/LLCP.2019.04 